\title{
The Impact of Human Activities on the Environment, Case of Mhondongori in Zvishavane, Zimbabwe
}

\author{
George Hove $^{1}\left(\mathbb{D}\right.$, Thomas Rathaha1, Precious Mugiya ${ }^{2}$ \\ ${ }^{1}$ Management College of Southern Africa, Durban, South Africa \\ ${ }^{2}$ Independent Consultant, Zvishavane, Zimbabwe \\ Email: ghove20@telkomsa.net, thomas.rathaha67@gmail.com
}

How to cite this paper: Hove, G., Rathaha, T., \& Mugiya, P. (2020). The Impact of Human Activities on the Environment, Case of Mhondongori in Zvishavane, Zimbabwe. Journal of Geoscience and Environment Protection, 8, 330-349. https://doi.org/10.4236/gep.2020.810021

Received: September 25, 2020

Accepted: October 27, 2020

Published: October 30, 2020

Copyright $\odot 2020$ by author(s) and Scientific Research Publishing Inc. This work is licensed under the Creative Commons Attribution International License (CC BY 4.0).

http://creativecommons.org/licenses/by/4.0/

\begin{abstract}
This study was proposed to explore the impact of human activities on the environment in Mhondongori. In this community, there are natural resources that include minerals, natural forest, wetlands, rivers and beautiful mountains. However, over the past two decades, the environmental quality of the community has deteriorated demonstrating irresponsible use of natural resources by humans. Indeed, if such poor natural resource management continues at the current rate, this would ultimately lead to extinction. Qualitative research design and convenience sampling methods were used. The study involved six participants who provided the data. An interview guide and observation techniques were used to collect data. Using content analysis data was classified into themes and a scorecard was used to determine the human activities on the environment and their impact. The results revealed that in Mhondongori, human activities that affected the environment were mining, veld fire, cutting down trees, overgrazing, excessive communal hunting and fishing, littering, water and air pollution. The impacts were the degradation of land, permanent scars on the landscape, deforestation, destruction of wildlife habitats, disappearance of wetlands, destruction of trees, grass, seed bank and seedlings, pollution of streets, bushes and rivers, disruption of migration and hibernation of animals. To conserve the environment, it was recommended that community leadership must develop appropriate environmental management strategies to mitigate these unfavourable impacts and that the state must empower Mhondongori leadership through reasonable legislative and other measures that would prevent environmental degradation.
\end{abstract}

\section{Keywords}

Environment, Environmental Management, Human Activities, 


\section{Introduction}

Over the past years, a range of environmental problems has been perceived to be major threats in Mhondongori, Zvishavane, Zimbabwe (Mayher, 2016). Issues of pollution, mining dumps, natural resource depletion, deforestation and land degradation have become common features in this community (Sibanda, 2016). While the subject of environmental management and its integration with development has become high on the community agenda, there have been growing human-induced environmental changes altering the ability of the natural environment to provide services (Mayher, 2016). In as much as many reports on mining, drought, agriculture, politics and land resettlement have been undertaken in Mhondongori, it seemed good for the researchers to deliver to the board of knowledge the impact of human activities on the environment focusing on Mhondongori community. In this community, the environment and its management have been and continue to be very topical issues. Existing environment and development reports emphasize listing problems, making warnings and voicing advocacy; this study, however, offers a different perspective. The researchers have moved on from the usual much-discussed viewpoints and provide an account of human activities to the environment specific to Mhondongori.

Mhondongori community is located in the Zvishavane Rural District Council in the Midlands province of Zimbabwe. While being one of the long-settled agricultural farming communities, it provides a home to 3000 people living in villages (Mayher, 2016). The community has a history of formal and informal gold and chrome mining and has recently hosted large scale platinum mining activities. The community is located at the southern end of the Great Dyke mineral belt, a 550-kilometre long seam of rock which hosts quantities of platinum, gold, nickel, copper and chrome. The area is well known for mining activities (Mayher, 2016). The formal mining in the area is conducted by Mimosa mine. The other players are small scale chrome mining, involving local individuals and small enterprises in partnership with Chinese firms. Chrome operations in Mhondongori are all surface mining or open-pit activities and are on claims belonging to Zimasco, a company mainly owned by the Chinese state company, Sinosteel Corporation. Zimasco operates a tributary system that gives out chrome mine claims to small scale or artisanal miners, which are then provided with inputs and mine the chrome before selling to Zimasco (Mayher, 2016). Apart from mining, community members practice subsistence farming and animal husbandry.

Even though environmental management is at the heart of every development, researchers have omitted to identify and examine the role played by human ac- 
tivity on the environment in Mhondongori, yet if the activities and their impacts could be considered; this could be a useful means to understand environmental management. A review of the literature has shown a relationship between all human activities and the environment (Mathe \& Phiri, 2016; Colby, 1991). Everything that humans do has some impact on the environment (Chandralatha et al., 2016). For example, pollution is a result of human activities in the environment and the main sources of pollution are farming, water pollution and air pollution (Owa, 2014). It is a human-induced or natural process which negatively affects the land to function effectively within an ecosystem by accepting, storing and recycling water, energy and nutrients (Chandralatha et al., 2016). Although this relationship is construed in other studies as mutually beneficial and ecologically sustainable, in Mhondongori humans extract benefits from nature to improve their chances of survival and quality of life, yet this is done in ways that harm and reduce local ecosystems' capacities to provide them in the future. In this case, the question that has remained unanswered in Mhondongori context is what impacts have been a result of human activities on the environment in Mhondongori community? This paper examines the impacts that have been caused by human activities in Mhondongori, based on a study that specifically sought to:

- To assess the human activities affecting the environment in Mhondongori community.

- To examine the impact of these activities on the environment in Mhondongori community.

- To characterise the measures that could assist the Mhondongori community in promoting sustainable environmental management.

\section{Literature Review}

As a result of environmental challenges, the issue of environmental management has become a desirable world over in recent years. In rural communities, activities such as agriculture and cropping patterns have a high environmental impact while in urban areas industrial and mining activities have also major impact to the environment. According to Martini et al. (2017), communities and other stakeholders have a responsibility to preserve and conserve the natural environment. But, what is the environment? This is a concept that has evolved over many decades; however, to-date there is no general agreement on exactly what it encompasses (Kotze \& Nel, 2009). Environment refers to the surroundings in which humans and other organisms exist. However, in many instances, its meaning is taken for granted while many commentators and officials discuss environmental issues without even attempting to define it (Strydon \& King, 2009). In South Africa a legal definition is provided by the National Environmental Management Act 107 of 1998-(NEMA) which defines the environment as the surroundings within which humans exist and that are made up of:

- Land, water and atmosphere of the earth, 
- Micro-organisms, plant and animal life,

- Any part or combination of the above, and the interrelationships among and between them and,

- The physical, chemical, aesthetic and cultural properties and conditions of the foregoing that influence human health and well-being.

While the above definition is important in guiding this study, one major problem the definition has is that it does not answer many questions, such as, how are cultural issues addressed in the definition and whether it relates to the built environment or natural environment.

Environmental management is defined as keeping control of the community's activities so that communities do what they can to conserve the physical resources and to avoid polluting them (Barrow, 2005). The same author further notes that environmental management has to cope with natural threats and problems caused by human activity. The main focus of environmental management is to manage the behaviour of humans and performance of organisations in line with environmental principles, criteria, standards and legislation (Strydon \& King, 2009) and is not concerned with the management of the environment. Therefore, prevention, supported by corrective actions is the centre of environmental management (Tinsley \& Pillai, 2012). A review of literature has shown that environmental management is shaped by a set of principles (Feris, 2010).

\subsection{Environmental Principles}

A variety of principles are used in environmental management. These principles help guide and shape the way people interact with the environment as nations develop. These principles that include the polluter pays principle, the precautionary principle, the prevention principle, the integration principle, the public participation principle and the sustainability principle have a bearing on this study. Furthermore, the principles are an anchor of sustainable development and ensure that the environment is not sacrificed on the altar of economic development (DEAT, 2004). They also have a wider application and have the broadest acceptance around the world. Each of the principles has been incorporated into international treaties and national law and based on their bearing on environmental issues; the principles have been included in this study.

\section{- The polluter pays principle}

The polluter pays principle (PPP) dictates that anyone who disturbs or spoils the environment in any way must take the necessary corrective measures to rectify the environment or pay for the cost of remediation (Environmental Management Agency, 2014). It is based on the moral basis of responsibility bearing in mind that the environment has so many uses to different people hence their ability to meet their needs must not be compromised by other people's activities. The PPP promotes economic efficiency in the implementation of pollution control policies and encourages business to control pollution in their activities. The PPP is one of the core principles of sustainable development and recognises that 
the polluter should pay for any environmental damage created and that the burden of proof in demonstrating that particular technology, practice or product is safe should lie with the developer, not the general public. For example, if a company pollutes a river which is a source of domestic, agricultural or recreational water for a given community then that company should either pay for the cost of cleaning up the river or the cost of the provision of the substitute sources of water such as the drilling of boreholes in the affected community (Environmental Management Agency, 2014).

\section{- The precautionary principle}

The precautionary principle approach is useful for social development as well as environmental issues. In developing countries like Zimbabwe, rural people have little in the way of security to fall back on if things like land reform or agricultural innovation fail. This means that developmental efforts in the country have to be right and there are preparations in place should there be problems. The principle of precautionary is constructed around the goal of preventing, rather than reacting to environmental harm (Applegate, 2002). Using this principle, it is important to take preventive action in the event of uncertainty, explore a wide range of alternatives to try and avoid unwanted impacts and to increase public participation in decision making. The principle demands 'upstream thinking', that is, looking for underlying causes of problems rather than fixing on symptoms. Further, it is important to ensure that a substance or activity posing a threat to the environment is prevented from adversely affecting the environment, even if there is no conclusive scientific proof of linking that particular substance or activity to environmental damage.

\section{- The integration principle}

The principle of integration is at the core of sustainable development. It encourages organisations to integrate environmental considerations into economic and other development (Rio Declaration, 1992; Stockholm Declaration, 1972). According to DEAT (2004), environmental management must be integrated, acknowledging that all elements of the environment are linked and interrelated, and it must take into account the effects of decisions on all components of the environment and all people in the environment. This principle has led many organisations to integrate environmental considerations into their decision-making processes through environmental impact assessment mandates.

\section{- The sustainability principle}

The sustainability principle encourages humans to develop their economic activities in such a way that the desired quality of life is secured or even raised while simultaneously reducing the use of natural resources. In this way, the basis of life for future generations could be preserved while opening up globally viable paths of development. In its draft policy on a framework for considering market-based instruments to support environmental fiscal reform in South Africa, The National Treasury Annual Report (2007/8) noted that, as the South African economy continues to develop, it is increasingly important to ensure that it does 
so in a sustainable way and that at the same time, issues of poverty and inequality are effectively addressed. Therefore, it is important to note that it's not just the quantity of growth that matters, but also it is quality. Human well-being and sustainable living are at the core of many countries' environmental agendas. One example, of sustainable development, is found in Sri Lanka where a tea estate that has been in production since the early 1920s is still a viable project (Jayaratne et al., 2011). The estate yields an export crop with minimal inputs such as pesticides. The same authors note that the tea bushes provide some slop protection cover to reduce soil erosion and at this altitude, on a poor and sloping soil few other tropical crops will not flourish. Also, green tourism has been added on, making use of existing access roads, to help ensure the profitability of tea production.

\subsection{Empirical Evidence}

A review of literature has shown that the world is facing environmental challenges emanating from human activities (Maponga, Ahmed, \& Manatsa, 2017; Matsvange et al., 2016; Dube, 2015; Mensah et al., 2015; Halder \& Islam, 2015; Nyamadzawo et al., 2013). These studies show that humans directly impact the environment in several ways that include mining activities, veld fires, water and air pollution, agricultural activities, fishing and hunting activities.

\subsubsection{Mining Activities}

Despite the policies and institutions that exist among countries, environmental degradation is still a major threat and concern (Mathe \& Phiri, 2016; Mensah et al., 2015; Syed et al., 2013; Kitula, 2006). In a study conducted by Mensah et al. (2015) in Ghana, it was found that the major rivers were heavily polluted by illegal small-scale miners; land in areas surrounding mines had been rendered bare and susceptible to increased erosion and loss of viability for agricultural purposes. The study found that increased clearing of vegetation for mining areas had adversely altered the hydrological regimes and patterns in the western region of Ghana, destruction of important soil organisms and disruption of stable soil aggregates were reported. As a result, a greater proportion of the land area had been rendered bare due to mining activities and large tracts of land had lost vegetation cover. In another study by Mathe \& Phiri (2016), open cast mining at Banket Mine in Zimbabwe impacted the topography of the earth, the plants and water which contributed to the loss of biodiversity around Blanket Mine. The same study found that land degradation was a result of the removal of trees and other plants by heavy machines and that the removal of nutrients altered the biological systems found in the soil and made it vulnerable to forces of erosion.

\subsubsection{Water Pollution}

One of the biggest impacts humans have on the environment is water pollution (Owa, 2014). Water pollution occurs when unwanted materials enter into the water sources, changes the quality of water and causes that water to become 
harmful to the environment and human health (Haseena et al., 2017). Water pollution has a duel effect on nature (Vishwanath et al., 2017). Water is a source of life, without it; there are negative effects on the living and the environment (Owa, 2014). Water pollution is an environmental problem that is of major concern to many nations worldwide (Halder \& Islam, 2015) and has been recognised as a problem since the 1970s (Skinner et al., 1997). The quality of water is affected by human activities by way of defecating, dumping of refuse, industrial wastes and washing of clothes (Owa, 2014). The resulting water pollution is a serious threat to the well-being and survival of aquatic and animals.

\subsubsection{Veld Fires}

Regardless of several Acts that aim at preventing fires, in Zimbabwe, veld fires remain a major environmental challenge (The Environmental Management Act (chapter 20: p. 27) of 2007 and The Parks and Wild Life Act (chapter 20: p. 14) of 2014). In a study conducted by Nyamadzawo et al. (2013) veld fires resulted from the influence that humans have on the natural environment. The impacts of fires were found to be multifaceted and were a threat to the biophysical, social and economic environment because of their trail of destruction. The impacts ranged from loss livelihoods and income, psychosocial impacts associated with fatalities and family bereavement, loss of biodiversity and disturbance of the hydrological balance. These findings are in line with Dube (2015) who found a similar result in a study conducted in Bulilima and Mangwe districts in southern Zimbabwe. In that study, most veld fires are a result of human actions emanating from the disposal of cigarettes, the burning of vegetation when preparing fields, the use of fire by hunters, smoking out bees and the making of fires by motorists along the highways. The impacts of veld fires were found to include property damage, reduced soil fertility, destruction of vegetation, air and water and destruction of wildlife.

\subsubsection{Farming}

For a long time, agriculture has been one of the most important factors that transform the environment (Skinner et al., 1997). The same authors found that the major environmental impacts associated with agriculture in the U.K. result from pesticides, nitrogen compounds, and pollution by farm livestock and soil erosion. In a study, Matsvange et al. (2016) found that the use of organic materials such as manure and compost were common crop management practice in the Nyanga, Zvimba and Guruve districts of Zimbabwe. It was found that the use of pesticides is mainly common in the gardens and farming methods promoted in the Nyanga, Zvimba and Guruve districts of Zimbabwe had a significant effect on land quality and subsequent cropping. In another empirical study conducted by Markus (2011) in Botswana overgrazing caused desertification in the Boteti area in central Botswana and that desertification had led to a reduction of the land productivity and availability of natural resources which negatively influence the environmental ecosystem. 


\section{Methodology}

A case study was conducted in Mhondongori of Zvishavane. The community was selected based on large-scale environmental devastation resulting from human activities in the area. The research was grounded in the phenomenology philosophy which assumes that human beings have subjective views of the social world they live in (Saunders et al., 2009: p. 116). Specifically, the study followed an exploratory research design (Robson, 2002). The aim was to take advantage of an empirical investigation of a contemporary phenomenon within a real-life context using multiple sources of evidence (observation and interviews). The qualitative approach involved interviewing the key informants to know the impact of human activities in the community (Flick, 2014). By using a qualitative approach, the aim was to collect detailed data from a small sample of representatives to gain insight in the phenomenon (Cooper \& Schindlr, 2011).

The target population was identified as local community leadership which was limited to local chiefs, headmen, headmasters and ward councillors (herein, reported as Key Informants A; B; C; D \& E as shown in table 1, 2 and 3). The chief is the head of the community and is well informed and alert to environmental problems. The chief provided the database of community leadership from which the sample was drawn using a convenience technique. The focus was on leadership because they form part of key decision-makers in the community. Mhondongori leadership is responsible for the well-being of the community and thus had information about all activities taking place. Further, they were in a position to offer information that would not be revealed by any community members. An interview guide was used as an instrument for the study. As part of the interview, informants were asked to describe human activities that affected the environment in Mhondongori over the past years. The data were summarised into six interview scripts written for each informant during the interview. Content analysis was used to analyse analysis.

\section{Results}

The empirical findings of the study are presented in this section. The informants from whom information was obtained comprised of 6 community leaders in Mhondongori as shown in Table 1.

\subsection{Demographic Information}

Table 1 shows that $67 \%$ of the informants were male while $33 \%$ were female demonstrating that the leadership of Mhondongori is dominated by male.

\subsection{Human Activities That Have Impacted the Environment in Mhondongori}

The informants were required to describe environmental human-induced activities in Mhondongori. From the analysis of the interview scripts, humans impacted the environment in several ways with land use, ranging from mining to agricultural activities. Table 2 summarised the activities as mentioned by the key 
informants A, B, C, D, E and F:

Ten major human activities affected the environment in Mhondongori. While all the activities identified were detrimental to the environment, their ranking showed that mining, veld fire, cutting down trees, overgrazing and hunting were the most critical, littering, fishery, pollution and crop farming were minor factors. Almost all the informants confirmed mining, veld fire and cutting down trees activities and these activities occupied the top on the table. The activities that were ranked at the bottom suggesting their level of insignificance were pollution and crop farming. From the scoring card, all the informants reported an average of six activities and this demonstrated the extent human activities have on the environment.

\subsection{Impact of Human Activities on the Environment in Mhondongori}

All the informants were asked the same question: "From your experience and knowledge, what do you consider to be the impact of the human activities described above?" The analysis of the interview scripts showed many and varied impacts as summarized in Table 3. Although the scripts reflected impacts of social, economic and environmental nature, the focus remained on the environmental impacts in line with the research objective.

Table 1. Profile of the informants.

\begin{tabular}{|c|c|c|c|c|c|c|}
\hline \multirow{2}{*}{ Study Area } & \multicolumn{6}{|c|}{ Key Informants } \\
\hline & A & B & $\mathrm{C}$ & $\mathrm{D}$ & $\mathrm{E}$ & $\mathbf{F}$ \\
\hline Gender & Male & Female & Male & Male & Male & Female \\
\hline Age group & 65 & 42 & 56 & 44 & 48 & 36 \\
\hline Qualification & Grade 5 & O-level & Grade 7 & O-level & Degree & O-level \\
\hline Profession & Farmer & Farmer & Farmer & Farmer & Businessman & Shop keeper \\
\hline
\end{tabular}

Table 2. Human activities that affect the environment in Mhondongori Community.

\begin{tabular}{|c|c|c|c|c|c|c|c|c|}
\hline Human Activity & A & B & $\mathrm{C}$ & D & $\mathrm{E}$ & $\mathbf{F}$ & Total & Rank \\
\hline Mining & $\mathrm{x}$ & $\mathrm{x}$ & $\mathrm{x}$ & $\mathrm{x}$ & $\mathrm{x}$ & $\mathrm{x}$ & 6 & 1 \\
\hline Veld fire & $\mathrm{x}$ & $\mathrm{x}$ & $\mathrm{x}$ & $\mathrm{x}$ & $\mathrm{x}$ & $\mathrm{x}$ & 6 & 1 \\
\hline Cutting down trees & $\mathrm{x}$ & $\mathrm{x}$ & $\mathrm{x}$ & $\mathrm{x}$ & $\mathrm{x}$ & $\mathrm{x}$ & 6 & 1 \\
\hline Overgrazing & $\mathrm{x}$ & $\mathrm{x}$ & $\mathrm{x}$ & - & $\mathrm{x}$ & $\mathrm{x}$ & 5 & 2 \\
\hline Littering & - & $\mathrm{x}$ & - & - & $\mathrm{x}$ & $\mathrm{x}$ & 3 & 4 \\
\hline Communal fishery & $\mathrm{x}$ & - & - & $\mathrm{x}$ & - & - & 2 & 5 \\
\hline Water pollution & - & - & $\mathrm{x}$ & - & - & $\mathrm{x}$ & 2 & 5 \\
\hline Air pollution & - & $\mathrm{x}$ & - & - & - & $\mathrm{x}$ & 2 & 6 \\
\hline Total score & 7 & 7 & 5 & 6 & 6 & 7 & 38 & \\
\hline
\end{tabular}

Legend: $\mathrm{x}=$ confirmed impact. 
Table 3. Impacts of human activities on the environment.

\begin{tabular}{|c|c|c|c|c|c|c|c|}
\hline \multirow{2}{*}{ Impact } & \multicolumn{6}{|c|}{ Key Informants } & \multirow{2}{*}{ Rank } \\
\hline & A & B & $\mathrm{C}$ & $\mathrm{D}$ & $\mathrm{E}$ & $\mathrm{F}$ & \\
\hline \multirow{12}{*}{ Mining } & Open pits & Open pits & Open pits & Open pits & Open pits & Open pits & 1 \\
\hline & Deforestation & Deforestation & Deforestation & Deforestation & Deforestation & Deforestation & 1 \\
\hline & Soil erosion & Soil erosion & Soil erosion & Soil erosion & Soil erosion & Soil erosion & 1 \\
\hline & $\begin{array}{l}\text { Water } \\
\text { contamination }\end{array}$ & $\begin{array}{l}\text { Water } \\
\text { contamination }\end{array}$ & $\begin{array}{l}\text { Water } \\
\text { contamination }\end{array}$ & $\begin{array}{l}\text { Water } \\
\text { contamination }\end{array}$ & $\begin{array}{l}\text { Water } \\
\text { contamination }\end{array}$ & $\begin{array}{l}\text { Water } \\
\text { contamination }\end{array}$ & 1 \\
\hline & $\begin{array}{l}\text { Permanent scars on } \\
\text { the landscape }\end{array}$ & $\begin{array}{l}\text { Permanent scars on } \\
\text { the landscape }\end{array}$ & $\begin{array}{l}\text { Permanent scars on } \\
\text { the landscape }\end{array}$ & $\begin{array}{l}\text { Permanent scars on } \\
\text { the landscape }\end{array}$ & $\begin{array}{l}\text { Permanent scars on } \\
\text { the landscape }\end{array}$ & $\begin{array}{l}\text { Permanent scars on } \\
\text { the landscape }\end{array}$ & 1 \\
\hline & $\begin{array}{l}\text { Destroy wildlife } \\
\text { habitats }\end{array}$ & $\begin{array}{l}\text { Destroy wildlife } \\
\text { habitats }\end{array}$ & $\begin{array}{l}\text { Destroy wildlife } \\
\text { habitats }\end{array}$ & $\mathrm{x}$ & $\begin{array}{l}\text { Destroy wildlife } \\
\text { habitats }\end{array}$ & $\begin{array}{l}\text { Destroy wildlife } \\
\text { habitats }\end{array}$ & 6 \\
\hline & $\begin{array}{l}\text { Dust and noise } \\
\text { pollution }\end{array}$ & $\mathrm{x}$ & $\begin{array}{l}\text { Dust and noise } \\
\text { pollution }\end{array}$ & $\begin{array}{l}\text { Dust and noise } \\
\text { pollution }\end{array}$ & $\mathrm{x}$ & $\begin{array}{l}\text { Dust and noise } \\
\text { pollution }\end{array}$ & 7 \\
\hline & $\mathrm{x}$ & Land degradation & $\mathrm{x}$ & Land degradation & Land degradation & Land degradation & 7 \\
\hline & $\begin{array}{l}\text { Poaching wild } \\
\text { animals }\end{array}$ & $\begin{array}{l}\text { Poaching wild } \\
\text { animals }\end{array}$ & $\mathrm{x}$ & $\mathrm{x}$ & $\begin{array}{l}\text { Poaching wild } \\
\text { animals }\end{array}$ & $\mathrm{x}$ & 9 \\
\hline & Lose of grazing land & & Lose of grazing land & & $\mathrm{x}$ & Lose of grazing land & 9 \\
\hline & $\begin{array}{l}\text { Disappearance of } \\
\text { wetlands }\end{array}$ & $\begin{array}{l}\text { Disappearance of } \\
\text { wetlands }\end{array}$ & $\mathrm{x}$ & $\mathrm{x}$ & $\begin{array}{l}\text { Disappearance of } \\
\text { wetlands }\end{array}$ & $\mathrm{x}$ & 9 \\
\hline & $\mathrm{x}$ & $\mathrm{x}$ & Global warming & $\mathrm{x}$ & $\mathrm{x}$ & Global warming & 12 \\
\hline \multirow{6}{*}{ Veld Fire } & $\begin{array}{l}\text { Destruction trees, } \\
\text { grass, seed bank and } \\
\text { seedlings. }\end{array}$ & $\begin{array}{l}\text { Destruction trees, } \\
\text { grass, seed bank and } \\
\text { seedlings. }\end{array}$ & $\begin{array}{l}\text { Destruction trees, } \\
\text { grass, seed bank } \\
\text { and seedlings. }\end{array}$ & $\begin{array}{l}\text { Destruction trees, } \\
\text { grass, seed bank } \\
\text { and seedlings. }\end{array}$ & $\begin{array}{l}\text { Destruction trees, } \\
\text { grass, seed bank } \\
\text { and seedlings. }\end{array}$ & $\begin{array}{l}\text { Destruction trees, } \\
\text { grass, seed bank } \\
\text { and seedlings. }\end{array}$ & 1 \\
\hline & $\begin{array}{l}\text { Destruction of } \\
\text { wildlife species }\end{array}$ & $\begin{array}{l}\text { Destruction of } \\
\text { wildlife species }\end{array}$ & $\begin{array}{l}\text { Destruction of } \\
\text { wildlife species }\end{array}$ & $\begin{array}{l}\text { Destruction of } \\
\text { wildlife species }\end{array}$ & $\begin{array}{l}\text { Destruction of } \\
\text { wildlife species }\end{array}$ & $\begin{array}{l}\text { Destruction of } \\
\text { wildlife species }\end{array}$ & 1 \\
\hline & $\begin{array}{l}\text { Affects animal } \\
\text { species functioning }\end{array}$ & $\begin{array}{l}\text { Affects animal } \\
\text { species functioning }\end{array}$ & $\begin{array}{l}\text { Affects animal } \\
\text { species functioning }\end{array}$ & $\begin{array}{l}\text { Affects animal } \\
\text { species functioning }\end{array}$ & $\begin{array}{l}\text { Affects animal } \\
\text { species functioning }\end{array}$ & $\begin{array}{l}\text { Affects animal } \\
\text { species functioning }\end{array}$ & 1 \\
\hline & Loss of soil fertility & Loss of soil fertility & $\mathrm{x}$ & Loss of soil fertility & Loss of soil fertility & Loss of soil fertility & 4 \\
\hline & $\begin{array}{l}\text { Air and water } \\
\text { pollution }\end{array}$ & $\mathrm{x}$ & $\begin{array}{l}\text { Air and water } \\
\text { pollution }\end{array}$ & $\mathrm{x}$ & $\begin{array}{l}\text { Air and water } \\
\text { pollution }\end{array}$ & $\begin{array}{l}\text { Air and water } \\
\text { pollution }\end{array}$ & 5 \\
\hline & $\mathrm{x}$ & $\begin{array}{l}\text { The reduced growth } \\
\text { rate of vegetation }\end{array}$ & $\begin{array}{l}\text { The reduced growth } \\
\text { rate of vegetation }\end{array}$ & $\mathrm{x}$ & $\mathrm{x}$ & $\begin{array}{l}\text { The reduced growth } \\
\text { rate of vegetation }\end{array}$ & 6 \\
\hline \multirow{7}{*}{$\begin{array}{l}\text { Cutting } \\
\text { Down Trees }\end{array}$} & Deforestation & Deforestation & Deforestation & Deforestation & Deforestation & Deforestation & 1 \\
\hline & Poor quality of land & Poor quality of land & Poor quality of land & Poor quality of land & Poor quality of land & Poor quality of land & 1 \\
\hline & $\begin{array}{l}\text { Disappearance of } \\
\text { wetlands }\end{array}$ & $\begin{array}{l}\text { Disappearance of } \\
\text { wetlands }\end{array}$ & $\begin{array}{l}\text { Disappearance of } \\
\text { wetlands }\end{array}$ & $\begin{array}{l}\text { Disappearance of } \\
\text { wetlands }\end{array}$ & $\begin{array}{l}\text { Disappearance of } \\
\text { wetlands }\end{array}$ & $\begin{array}{l}\text { Disappearance of } \\
\text { wetlands }\end{array}$ & 1 \\
\hline & $\begin{array}{l}\text { Loss of habitat for } \\
\text { millions of species }\end{array}$ & $\begin{array}{l}\text { Loss of habitat for } \\
\text { millions of species }\end{array}$ & $\begin{array}{l}\text { Loss of habitat for } \\
\text { millions of species }\end{array}$ & $\begin{array}{l}\text { Loss of habitat for } \\
\text { millions of species }\end{array}$ & $\begin{array}{l}\text { Loss of habitat for } \\
\text { millions of species }\end{array}$ & $\begin{array}{l}\text { Loss of habitat for } \\
\text { millions of species }\end{array}$ & 1 \\
\hline & $\mathrm{x}$ & Climate change & Climate change & Climate change & $\mathrm{x}$ & Climate change & 5 \\
\hline & $\begin{array}{l}\text { The emergence of } \\
\text { barren desserts }\end{array}$ & $\mathrm{x}$ & $\mathrm{x}$ & $\begin{array}{l}\text { The emergence of } \\
\text { barren desserts }\end{array}$ & $\begin{array}{l}\text { The emergence of } \\
\text { barren desserts }\end{array}$ & $\begin{array}{l}\text { The emergence of } \\
\text { barren desserts }\end{array}$ & 5 \\
\hline & $\begin{array}{l}\text { The disappearance } \\
\text { of the forest canopy }\end{array}$ & $\mathrm{x}$ & $\begin{array}{l}\text { The disappearance } \\
\text { of the forest canopy }\end{array}$ & $\mathrm{x}$ & $\begin{array}{l}\text { The disappearance } \\
\text { of the forest canopy }\end{array}$ & $\mathrm{x}$ & 7 \\
\hline
\end{tabular}




\section{Continued}

\begin{tabular}{|c|c|c|c|c|c|c|c|}
\hline & $\mathrm{x}$ & $\begin{array}{l}\text { Destruction of } \\
\text { ecosystems }\end{array}$ & $\begin{array}{l}\text { Destruction of } \\
\text { ecosystems }\end{array}$ & $\mathrm{x}$ & $\mathrm{x}$ & $\begin{array}{l}\text { Destruction of } \\
\text { ecosystems }\end{array}$ & 7 \\
\hline & $\mathrm{x}$ & Soil erosion & Soil erosion & $\mathrm{x}$ & Soil erosion & $\mathrm{x}$ & 7 \\
\hline & $\begin{array}{l}\text { Loss of ground } \\
\text { nutrients }\end{array}$ & $\mathrm{x}$ & $\begin{array}{l}\text { Loss of ground } \\
\text { nutrients }\end{array}$ & $\mathrm{x}$ & $\mathrm{x}$ & $\mathrm{x}$ & 10 \\
\hline \multirow{3}{*}{ Overgrazing } & Soil erosion & Soil erosion & Soil erosion & Soil erosion & Soil erosion & Soil erosion & 1 \\
\hline & Land degradations & Land degradation & Land degradation & Land degradation & Land degradation & Land degradation & 1 \\
\hline & $\begin{array}{l}\text { Loss of valuable } \\
\text { species }\end{array}$ & $\begin{array}{l}\text { Loss of valuable } \\
\text { species }\end{array}$ & $\begin{array}{l}\text { Loss of valuable } \\
\text { species }\end{array}$ & $\begin{array}{l}\text { Loss of valuable } \\
\text { species }\end{array}$ & $\begin{array}{l}\text { Loss of valuable } \\
\text { species }\end{array}$ & $\begin{array}{l}\text { Loss of valuable } \\
\text { species }\end{array}$ & 1 \\
\hline \multirow{4}{*}{ Littering } & $\begin{array}{l}\text { Pollutes streets, } \\
\text { bushes and rivers }\end{array}$ & $\begin{array}{l}\text { Pollutes streets, } \\
\text { bushes and rivers }\end{array}$ & $\begin{array}{l}\text { Pollutes streets, } \\
\text { bushes and rivers }\end{array}$ & $\begin{array}{l}\text { Pollutes streets, } \\
\text { bushes and rivers }\end{array}$ & $\begin{array}{l}\text { Pollutes streets, } \\
\text { bushes and rivers }\end{array}$ & $\begin{array}{l}\text { Pollutes streets, } \\
\text { bushes and rivers }\end{array}$ & 1 \\
\hline & $\begin{array}{l}\text { Harm livestock and } \\
\text { wildlife }\end{array}$ & $\begin{array}{l}\text { Harm livestock and } \\
\text { wildlife }\end{array}$ & $\begin{array}{l}\text { Harm livestock and } \\
\text { wildlife }\end{array}$ & $\begin{array}{l}\text { Harm livestock and } \\
\text { wildlife }\end{array}$ & $\begin{array}{l}\text { Harm livestock and } \\
\text { wildlife }\end{array}$ & $\begin{array}{l}\text { Harm livestock and } \\
\text { wildlife }\end{array}$ & 1 \\
\hline & Fire hazard & Fire hazard & Fire hazard & Fire hazard & Fire hazard & Fire hazard & 1 \\
\hline & $\begin{array}{l}\text { Changes the image } \\
\text { of places }\end{array}$ & $\mathrm{x}$ & $\begin{array}{l}\text { Changes the image } \\
\text { of places }\end{array}$ & $\mathrm{x}$ & $x$ & $\begin{array}{l}\text { Changes the image } \\
\text { of places }\end{array}$ & 4 \\
\hline \multirow{3}{*}{$\begin{array}{l}\text { Excessive } \\
\text { communal } \\
\text { hunting }\end{array}$} & $\begin{array}{l}\text { Destruction of } \\
\text { biosphere }\end{array}$ & $\begin{array}{l}\text { Destruction of } \\
\text { biosphere }\end{array}$ & $\begin{array}{l}\text { Destruction of } \\
\text { biosphere }\end{array}$ & $\begin{array}{l}\text { Destruction of } \\
\text { biosphere }\end{array}$ & $\begin{array}{l}\text { Destruction of } \\
\text { biosphere }\end{array}$ & $\begin{array}{l}\text { Destruction of } \\
\text { biosphere }\end{array}$ & 1 \\
\hline & $\begin{array}{l}\text { Extinctions of } \\
\text { animal species }\end{array}$ & $\begin{array}{l}\text { Extinctions of } \\
\text { animal species }\end{array}$ & $\mathrm{x}$ & $\begin{array}{l}\text { Extinctions of } \\
\text { animal species }\end{array}$ & $\begin{array}{l}\text { Extinctions of } \\
\text { animal species }\end{array}$ & $\begin{array}{l}\text { Extinctions of } \\
\text { animal species }\end{array}$ & 2 \\
\hline & $\begin{array}{l}\text { Disrupts migration } \\
\text { and hibernation of } \\
\text { animals }\end{array}$ & $\mathrm{x}$ & $\begin{array}{l}\text { Disrupts migration } \\
\text { and hibernation of } \\
\text { animals }\end{array}$ & $\begin{array}{l}\text { Disrupts migration } \\
\text { and hibernation of } \\
\text { animals }\end{array}$ & $\mathrm{x}$ & $\begin{array}{l}\text { Disrupts migration } \\
\text { and hibernation of } \\
\text { animals }\end{array}$ & 3 \\
\hline \multirow{2}{*}{$\begin{array}{l}\text { Excessive } \\
\text { communal } \\
\text { fishery }\end{array}$} & $\begin{array}{l}\text { Extinction of fish } \\
\text { species }\end{array}$ & $\begin{array}{l}\text { Extinction of fish } \\
\text { species }\end{array}$ & $\begin{array}{l}\text { Extinction of fish } \\
\text { species }\end{array}$ & $\begin{array}{l}\text { Extinction of fish } \\
\text { species }\end{array}$ & $\begin{array}{l}\text { Extinction of fish } \\
\text { species }\end{array}$ & $\begin{array}{l}\text { Extinction of fish } \\
\text { species }\end{array}$ & 1 \\
\hline & $\begin{array}{l}\text { Disruption of } \\
\text { ecosystem }\end{array}$ & $\begin{array}{l}\text { Disruption of } \\
\text { ecosystem }\end{array}$ & $\begin{array}{l}\text { Disruption of } \\
\text { ecosystem }\end{array}$ & $\begin{array}{l}\text { Disruption of } \\
\text { ecosystem }\end{array}$ & $\begin{array}{l}\text { Disruption of } \\
\text { ecosystem }\end{array}$ & $\begin{array}{l}\text { Disruption of } \\
\text { ecosystem }\end{array}$ & 1 \\
\hline \multirow{3}{*}{$\begin{array}{l}\text { Water } \\
\text { pollution }\end{array}$} & $\begin{array}{l}\text { Contamination of } \\
\text { water sources }\end{array}$ & $\begin{array}{l}\text { Contamination of } \\
\text { water sources }\end{array}$ & $\begin{array}{l}\text { Contamination of } \\
\text { water sources }\end{array}$ & $\begin{array}{l}\text { Contamination of } \\
\text { water sources }\end{array}$ & $\begin{array}{l}\text { Contamination of } \\
\text { water sources }\end{array}$ & $\begin{array}{l}\text { Contamination of } \\
\text { water sources }\end{array}$ & 1 \\
\hline & $\begin{array}{l}\text { Death of water } \\
\text { animals }\end{array}$ & $\begin{array}{l}\text { Death of water } \\
\text { animals }\end{array}$ & $\begin{array}{l}\text { Death of water } \\
\text { animals }\end{array}$ & $\begin{array}{l}\text { Death of water } \\
\text { animals }\end{array}$ & $\begin{array}{l}\text { Death of water } \\
\text { animals }\end{array}$ & $\begin{array}{l}\text { Death of water } \\
\text { animals }\end{array}$ & 1 \\
\hline & Damages ecosystem & Damages ecosystem & Damages ecosystem & Damages ecosystem & Damages ecosystem & Damages ecosystem & 1 \\
\hline \multirow{5}{*}{$\begin{array}{l}\text { Air } \\
\text { pollution }\end{array}$} & Climate change & Climate change & Climate change & Climate change & Climate change & Climate change & 1 \\
\hline & $\begin{array}{l}\text { Damages plants and } \\
\text { vegetation }\end{array}$ & $\begin{array}{l}\text { Damages plants and } \\
\text { vegetation }\end{array}$ & $\begin{array}{l}\text { Damages plants and } \\
\text { vegetation }\end{array}$ & $\begin{array}{l}\text { Damages plants and } \\
\text { vegetation }\end{array}$ & $\begin{array}{l}\text { Damages plants and } \\
\text { vegetation }\end{array}$ & $\begin{array}{l}\text { Damages plants and } \\
\text { vegetation }\end{array}$ & 1 \\
\hline & Damages ecosystem & Damages ecosystem & Damages ecosystem & Damages ecosystem & Damages ecosystem & Damages ecosystem & 1 \\
\hline & $\begin{array}{l}\text { Wildlife health } \\
\text { problem }\end{array}$ & $\mathrm{x}$ & $\mathrm{x}$ & $\begin{array}{l}\text { Wildlife health } \\
\text { problem }\end{array}$ & $\mathrm{x}$ & $\begin{array}{l}\text { Wildlife health } \\
\text { problem }\end{array}$ & 4 \\
\hline & $\mathrm{x}$ & $\begin{array}{l}\text { Reduces tree and } \\
\text { grass seedlings }\end{array}$ & $x$ & $\begin{array}{l}\text { Reduces tree and } \\
\text { grass seedlings }\end{array}$ & $\begin{array}{l}\text { Reduces tree and } \\
\text { grass seedlings }\end{array}$ & $\mathrm{x}$ & 4 \\
\hline \multirow{2}{*}{$\begin{array}{l}\text { Crop } \\
\text { Farming }\end{array}$} & Soil erosion & Soil erosion & Soil erosion & Soil erosion & Soil erosion & Soil erosion & 1 \\
\hline & Deforestation & Deforestation & Deforestation & Deforestation & Deforestation & Deforestation & 1 \\
\hline
\end{tabular}

Legend: $\mathrm{x}=$ no variable confirmed. 


\subsubsection{Impact of Mining Activities}

The informants reported twelve impacts caused by informal mining activities in Mhondongori. All the informants reported the open pits that are left by informal mining companies as indicated in Table 3, for example, informant B said: "There are numerous deep open, unsecured and un-rehabilitated mining pits most of which are now water pools". Informant D, H and F emphasised that "the scope of the problem has grown significantly in the community, with the erosion of soil, contamination of water, destruction of wildlife habitats, poaching of wildlife and deforestation". Interestingly, all informants complained that informal mining had caused permanent scars on the landscape, the beauty of Mhondongori and its surroundings and had caused deforestation. They mentioned trees and vegetation which were cleared and burnt to clear for mining. Informants A, B and E complained that mining had caused the disappearance of wetlands and had directly affected the ecosystem and its stability as many species had been killed due to toxicity of water and soil. All informants agreed that mining had caused massive land degradation in Mhondongori. Further, grazing land for their livestock is fast diminishing threatening livestock production which is a significant source of food, income and power for tilling the land. The results agree with Mensah et al. (2015) who found that mining operations by illegal small scale carried out in the open air without appropriate safeguards and environmental standards released contaminated water into the surrounding environment, thereby polluting nearby rivers, soils and vegetation.

The researcher had the opportunity to drive around Mhondongori with informants D and F. Massive destruction of the environment was observed. There were open pits about forty metres deep abandoned by small-scale miners. As we drove around, $\mathrm{D}$ and $\mathrm{F}$ bemoaned the massive land degradation in the area. They claimed most of the prime farmland had been taken over by the informal miners who left unsecured pits once they had done with their mining activities. "We no longer have arable farmland because our land has been invaded by small scale miners" informant $\mathrm{D}$ argued. Of concern was that community leaders were not consulted or even informed about the background of the informal mining companies (popularly known as "Makorokoza").

\subsubsection{Impact of Veld Fire Activities}

On veld fires, six impacts were reported as indicated in Table 3. This finding was in line with Nyamadzawo et al. (2013) who reported that impacts of fires are multifaceted because of their trail of destruction ranging from loss of livelihoods, loss of biodiversity and disturbance of the hydrological balance. The entire informants in this study reported the veld fire that occurs during the winter period in Zimbabwe. Of concern were the dangers that veld fires pose to the environment that included the destruction of trees, grass, seed bank and seedlings. Informant A complained that the community was losing grazing land for livestock through veld-fires. Other dangers mentioned by the entire informants included the destruction of wildlife species, loss of soil fertility, and reduction of the 
growth rate of vegetation, air and water pollution. This result confirmed Dube (2015) who had a similar finding in the Bulilima and Mangwe districts. In that study, veld fires had posed major challenges to the environment such as soil fertility, destruction of vegetation, wildlife, and air and water pollution. This result is also in line with The Sunday Mail (2016) that reported veld fires in Zimbabwe which had become a major driver of land degradation and biodiversity loss.

\subsubsection{Impact of Cutting Down Trees}

All the informants narrated how local people cut down trees and grass in Mhondongori for their use and this was a major challenge for Mhondongori. There were ten impacts reported on this theme. People cut down trees to provide room for planting crops, to build huts and kraals and to provide firewood as a source of energy. As reported by the entire informants, cutting down trees had become a major driver of deforestation, caused the poor quality of land, disappearance of wetlands and loss of habitat for millions of species in Mhondongori. Another concern raised by informant $\mathrm{D}$ was that members of the community have a tendency of cutting down trees to sell firewood to the urban residence and this has become a major source of income for them. Ironically, this has caused deforestation in the area. This impact is in line with Matsvange et al. (2016) who conducted a study in Nyanga, Zvimba and Guruve districts of Zimbabwe and found deforestation having a major impact on the environment. This was a result of the on-going activities in agrarian reform and access to community forests in some districts. Due to cutting down trees, Mhondongori had been transformed from its thick forest to terrain with little vegetation.

\subsubsection{Impact of Overgrazing}

The entire informants mentioned continuous or rotational grazing in Mhondongori. Some community members have a large herd of cattle, goats and sheep which are kept on a small area and overgrazing is highly susceptible. With too many cattle in the community and the grazing activities which are not properly controlled, this has resulted in soil degradation and vegetation destruction. It was reported that cattle and goats feed on young plants and seeds and this has reduced the growth and survival of vegetation and caused soil erosion. Informant G said: "Overgrazing has decreased plant density and this has reduced sunlight interception and plant growth in Mhondongori”. This result confirmed Markus (2011) who researched Botswana on the impact of overgrazing on desertification. In the study, it was found that overgrazing had caused desertification in the Boteti area in central Botswana.

\subsubsection{Impact of Littering}

On littering, it was reported that people were so careless and negligent as they throw garbage (bottles, glasses and plastic papers) anywhere and this harmed the environment, pets and wildlife. There were 4 impacts reported on this activity. All informants gave examples of bottles, papers and plastics which are dumped along the road and in the open field. Informants B, C and E said: "Our cattle 
feed on the plastic and die as a result". As the researcher drove around, plenty of garbage of plastics and beer cans scattered in the bushes and along the roads were observed. This has caused harm to the environment as livestock and animals feed on the litter especially plastics. The other impact reported was that litter was a fire hazard. This study confirmed Moates (2018) who established that plastics entering the marine ecosystem may be ingested by birds, fish and cetaceans while on land, the littering of transport corridors such as roads can result in the entanglement of medium-sized species in multi-pack plastic rings and entrapment of small mammals.

\subsubsection{Impact of Excessive Communal Fishery and Hunting}

There is uncontrolled exploitation of fishing along the local river which has caused significant stock depletion as reported by the entire informants. Although some communal people embark on fishing activities to provide food to their families, some embark on this activity as a source of income. It was reported that communal fishing had posed danger to the fish population and habitat destruction, mainly because of the fishing techniques used. For example, informants A, H, E reported that fishermen use fishing nets along the bottom of the river pools and this practice harmed riverbed life on a single run and fish populations. Of concern was that the river ecosystem had collapsed due to the destruction in the food chain. The entire informants also reported excessive hunting of wild animals in Mhondongori which was done to provide the family with bush meat.

\subsubsection{Impact of Water Pollution}

The entire informants reported sources water in Mhondongori that had been polluted as a result of containments that enter water bodies through run-off from agricultural fields and roads. Major sources of water including nearby Negi river had been polluted by many substances including garbage dumping by local people and dangerous chemicals used by Makorokoza. Ngezi River serves as the main source of water for wildlife and community livestock and the river had been heavily polluted by human-induced activities. Of concern was the creatures affected that depend on the water such as fish, crabs and birds. These creatures die because their living environments are polluted by harmful pesticides, fertilizers and plastics which are discharged by community members into these creatures' environment. This result is in line with Owa (2014) who found that excess use of fertilizer, herbicides and pesticides when washed by rain into rivers cause danger to life especially when water is the source of drinking.

\subsubsection{Impact on Air Pollution}

The entire informants confirmed land degradation in Mhondongori over the last few years which resulted in air pollution. Informant D said: "There is no clean air in this community." It was reported that harmful particles emitted from agricultural fields and mining dumps are carried away from their sources and fell on the land and water surface. This damaged plants and vegetation of the 
surrounding natural area. The wild animals living in ecosystems are suffering greatly from the negative impacts of air pollution. The informants believed the community is inhaling dust particles which emanate from the fields and mine dumps. The result is in line with Mathe \& Phiri (2016) who reported that mining activities do pollute the air, the land as well as sources of water.

\subsubsection{Impact on Crop Farming}

Although crop farming was reported as the source of livelihoods in Mhondongori, there were concerns that it had caused deforestation and soil erosion. It was reported that some crops are grown on the same land year after year and this resulted in soil erosion. Further, when these farmers intend to increase areas for cultivation, they cut down trees and other plants and this caused habitat loss and threatened the survival of numerous species of animals and plants. Significant environmental issues associated with crop farming were reported, informants B, $\mathrm{G}, \mathrm{H}$, and $\mathrm{D}$ mentioned fertilisers, chemicals and organic materials which damage soil and had affected wildlife habitats in the area. Similarly, the use of fertilisers and organic material is the most common crop management practice in Nyanga, Zvimba and Guruve districts of Zimbabwe (Matsvange et al., 2016).

\subsubsection{Positive Impacts}

The entire informants were angry about human activities experienced in Mhondongori and did not want to be drawn into much discussion on positive impacts as they felt nothing good came out from human activities. An analysis of their scripts showed their disagreement with the view that win-win opportunities exist with regards to human activities. The main point was on the enormous environmental impacts which in their views no positive return can be provided as a genuine reason to argue against any real benefit arising from human activities experienced in Mhondongori. Although the researcher did not engage in the informants' frustration, it was evident that there are tensions among community members, informal mining companies and some government departments.

\section{Discussions}

The results of this study show that Mhondongori community members rely heavily on natural resources and on the goods that ecosystems provide. The goods are the benefits the community derives from nature which includes minerals, water, air, and fuelwood. However, in the process of accessing these goods, the community indulges in destructive activities such as mining activities, farming activities, communal fishery and hunting activities. There is much pressure exerted on Mhondongori environment by the community and this has resulted in the deterioration of environmental quality, land degradation, poor quality of air and water, destruction of wildlife and ecosystem as described by the informants.

Although the environmental principles help to guide and shape the way people interact with the environment, the empirical evidence in this study does 
not show the application or enforcement of these principles in Mhondongori. For example, the polluter pays principle contends that firms should be charged for the full costs to society of their current pollution (Tilton, 2016). The polluters should pay for the environmental costs of their pollution and this is the most principle of justice and responsibility. The entire informants confirmed that informal small scale miners are not held accountable for many of the costs that their operations impose on the environment. These miners should be made accountable for their actions in Mhondongori. The principle should be implemented so that the current producers pay full costs to the community of the actions including the cleaning up of mining sites.

While agriculture is a source of livelihood for the community, the results have shown that agriculture has contributed substantially to environmental degradation in Mhondongori. Vegetation is cleared for agricultural expansion resulting in deforestation. The entire informants reported incidences of veld fire which are caused by community members trying to prepare the land for agriculture. These human activities have a devastating effect on the environment and cause deforestation.

Although the principle of integration encourages organisations to integrate environmental consideration into economic and other development (Rio Declaration, 1992), the participation of Mhondongori community members especially in the enforcement of environmental issues is insignificant. It was noted that there were programs where community members were educated through indabas and discussions about environmental preservation. According to Informant $B$, most community members agreed about environmental management and protection during indaba sessions. However, the enforcement of these programmes is the major problem because immediately after the indabas some community members engaged in activities that damaged the environment and the community leaders could not control them. The traditional leaders have less power and have limited space for participation in local decision making to enforce traditional regulations affecting the environment. As reported by The Sunday Mail (2016), in the past, traditional leaders were the custodian of the environment and its natural resources. However, this lack of enforcement of environmental rules and regulations by community leadership is one of the key natural resource management issues contributing to deforestation in Zimbabwe (Marufu, 2012).

\section{Ethical Considerations}

In this study, the rights of the informants were taken into consideration. In line with Greener \& Martelli (2012) who defines ethics in research as morale principles affecting the decision, standard and behaviour, ethical principles observed in this study included seeking permission from local leadership to conduct the study, getting informed consent from research participants and respecting the confidentiality and anonymity of the research participants and avoiding harming the research participants. 


\section{Trustworthiness}

The trustworthiness of data was achieved in this study through triangulation. Triangulation is the use of different data collection methods within one study to ensure that the data are telling you what you think they are telling you (Saunders et al., 2009). Triangulation was accomplished by asking the informants same research question and by visiting sites to observe the situation described by the informants.

\section{Practical Implications}

The findings of this study could have important implications for Mhondongori. Particular attention should be taken on the following implications:

\section{- The environmental principles}

While the environmental principles provide a basic guide and shape how humans interact with the environment, the enforcement of the principles in Mhondongori seems to be non-existent, however, if they do exist, the implementation of such enforcement has been practically ineffective. Such enforcement should start by activities that include carrying out field inspections of the environment, sampling and monitoring water quality and monitoring air emissions to verify compliance. Prospecting offenders should be punished in line with the applicable principle, for example, the polluter must pay principle. This principle can be applied in the event the offender polluted the environment. Such enforcement would encourage the community to act promptly to rectify any pollution problems. However, the action taken must be fair, consistent and transparent. If the principle is to be applied fairly, it must be ascertained that the polluter has degraded the environment and the extent of degradation should be given a monetary value.

\section{- Human activities and impact on the environment}

The study in Mhondongori has enabled us to understand the human activities and their impacts on the environment in the community. The results have shown that human activities degrade the environment. The results show that community members have realised that most of the environmental damages are man-made and the challenge is to find a mechanism to contain the situation. Therefore, appropriate environmental management strategies must be developed by the community leadership to mitigate these unfavourable impacts.

\section{Limitations to the Study}

This study was limited to the community leaders and did not verify whether the activities and impacts raised are caused by people of Mhondongori alone.

\section{Conclusion and Further Work}

The impacts of human activities on the environment in Mhondongori were presented in this paper. Human activities that harm the environment were identified. Human activities have caused serious damages to the Mhondongori area. 
Community members have come to realise that their activities have caused deforestation, changing the texture of soil and that their actions have a range of damaging ecological effects. Those activities have also contributed towards the loss of natural habitat for the wild animals to live resulting in their extinction. To avoid any further adverse impact on the environment in Mhondongori, there is need for the state to empower community leadership through reasonable legislative and other measures that would prevent environmental degradation. Through such measures, the community would have an obligation to protect the environment for both present and future generations. Increased participation by the community in environmental issues in this community is vital. A qualitative approach was used in this study; hence the results cannot be generally applicable to all communities in Zimbabwe. However, a quantitative approach should be conducted to validate the results of this study.

\section{Acknowledgements}

To our research assistants, Blessed Hove and Tafadzwa Hove guided by Precious Mugiya, you played an integral role in this study.

\section{Conflicts of Interest}

The authors declare no conflicts of interest regarding the publication of this paper.

\section{References}

Applegate, J. S. (2002). The Taming of the Precautionary Principle. Maurer Faculty, Paper 439. http://www.repository.law.indiana.edu/facpub/439

Barrow, C. J. (2005). Environmental Management and Development (2nd ed.). London: Routledge. https://doi.org/10.4324/9780203016671

Chandralatha, W. M. G., Yapa, L. G., \& Masheshika, E. (2016). The Necessity for an Application of Environmental Management into Rural Areas (Special Reference to Malimboda Divisional Secretariat Division). International Journal of Multidisciplinary Studies, 3, 131-140. https://doi.org/10.4038/ijms.v3i2.15

Colby, M. E. (1991). Environmental Management in Development: The Evolution of Paradigms. Ecological Economics, 3, 193-213. https://doi.org/10.1016/0921-8009(91)90032-A

Cooper, D. R., \& Schindler, P. S. (2011). Business Research Methods (11th ed.). New York: McGraw-Hill International Edition.

DEAT (2004). Overview of Integrated Environmental Management, Integrated Environmental, Information Series 0. Pretoria: Department of Environmental Affairs and Tourism (DEAT).

Dube, E. (2015). Environmental Challenges Posed by Veld Fires in Fragile Regions: The Case of the Bulilima and Mangwe Districts in Southern Zimbabwe. Jàmbá: Journal of Disaster Risk Studies, 7, a224. https://doi.org/10.4102/jamba.v7i1.224

Environmental Management Agency (2014). Environmental Management Principles. https://www.herald.co.zw/environmental-management-principles/

Feris, L. A. (2010). The Role of Good Environmental Governance in the Sustainable De- 
velopment of South Africa. PER, 13, 73-99. https://doi.org/10.4314/pelj.v13i1.55354

Flick, U. (2014). An Introduction to Qualitative Research (6th ed.). Germany: Sage Publishing.

Greener, S., \& Martelli, J. (2012). An Introduction to Business Research Methods (3rd ed.). UK: Ventus Publishing.

Halder, N. H., \& Islam, M. N. (2015). Water Pollution and Its Impact on Human Health. Journal of Environment and Human, 2, 36-46.

Haseena, M., Malik, M. F., Javed, A., Arshad, S., Asif, N., Zulfiqar, S., \& Hanif, J. (2017). Water Pollution and Human Health. Environmental Risk Assessment and Remediation, 1, 16-19. https://doi.org/10.4066/2529-8046.100020

Jayaratne, P., Styger, L., \& Perera, N. (2011). Sustainable Supply Chain Management: Using the Sri Lankan Tea Industry as a Pilot Study. In 25th Annual Australia New Zealand Academy of Management Conference (ANZAM 2011) (pp. 1-22). New Zealand: ANZAM.

Kitula, A. G. N. (2006). The Environmental and Socio-Economic Impacts of Mining on Local Livelihoods in Tanzania: A Case Study of Geita District. Journal of Cleaner Production, 14, 405-414. https://doi.org/10.1016/j.jclepro.2004.01.012

Kotze, L. J., \& Nel, J. G. (2009). Environmental Management: An Introduction. In Fuggle and Rabie's Environmental Management in South Africa. Cape Town: Juta.

Maponga, R., Ahmed, F., \& Manatsa, D. (2017). Determination of Veld Fire Hazard Zones in Multiple Tenure Systems in Zimbabwe: Implications for Intervention. Environmental and Ecology Research, 5, 409-421. https://doi.org/10.13189/eer.2017.050601

Markus, M. H. (2011). The Impact of Overgrazing on Desertification: A Case Study in Botswana at the Mopipi Study Site of the Desire Project. Wageningen University, Land Degradation and Development Group.

Martini, U., Buffa, F., \& Notaro, S. (2017). Community Participation, Natural Resource Management and the Creation of Innovative Tourism Products: Evidence from Italian Networks of Reserves in the Alps. Sustainability, 9, 2314. https://doi.org/10.3390/su9122314

Marufu, A. (2012). Status of Deforestation in Zimbabwe. http://www.herald.co.zw/status-of-deforestation-in-zim/

Mathe, M., \& Phiri, A. (2016). The Impact of Mining on the Environment in Gwanda District Zimbabwe: A Case Study of Blanket Mine. Imperial Journal of Interdisciplinary Research (IJIR), 2, 503-512.

Matsvange, D., Sagonda, R., \& Kaundikiza, M. (2016). The Role of Communities in Sustainable Land and Forest Management: The Case of Nyanga, Zvimba and Guruve Districts of Zimbabwe. Jàmbá: Journal of Disaster Risk Studies, 8, a281. https://doi.org/10.4102/jamba.v8i3.281

Mayher, A. (2016). The Need for Model Mining Legislation: Case Studies on the Impact of Mining in Angola, Democratic Republic of Congo, Kenya and Zimbabwe. IANRA, International Alliance on Natural Resources in Africa.

Mensah, A. K., Mahiri, I. O., Owusu, O., Mireku, O. D., Wireko, I., \& Kissis, E. A. (2015). Environmental Impacts of Mining: A Study of Mining Communities in Ghana. Applied Ecology and Environmental Sciences, 3, 81-94.

Moates, G. (2018). Small Mammal Mortality in Discarded Bottles and Drinks Cans: A Norfolk-Based Field Study in a Global Context. Journal of Litter and Environmental Management, 2, 5-13.

Nyamadzawo, G., Gwenzi, W., Kanda, A., Kundhlande, A., \& Masona, C. (2013). Under- 
standing the Causes, Socio-Economic and Environmental Impacts and Management of Veld Fires in Tropical Zimbabwe. Fire Science Reviews, 2, 2-13.

https://doi.org/10.1186/2193-0414-2-2

Owa, F. W. (2014). Water Pollution: Sources, Effects, Control and Management. International Letters of Natural Sciences, 8, 1-6. https://doi.org/10.18052/www.scipress.com/ILNS.8.1

Rio Declaration (1992). Rio Declaration on Environment and Development, in the Report of the United Nations Conference on Environment and Development. UN Doc. A/CONF.151/26 (Vol. 1), 12 August 1992.

Robson, C. (2002). Real-World Research: A Resource for Social Scientists and Practitioner-Researchers (2nd ed.). Oxford: Blackwell.

Saunders, M., Lewis, P., \& Thornhill, A. (2009). Research Methods for Business Students (5th ed.). New York: Prentice-Hall Financial Times.

Sibanda, M. (2016). Community Voices on Mining: A Narrative and Picture Testament of the Impacts of Chrome Mining Activities in Zvishavane. Zimbabwe Environmental Law Association.

Skinner, J. A., Lewis, K. A., Bardon, K. S., Tucker, P., Catt, J. A., \& Chambers, B. J. (1997). An Overview of the Environmental Impact of Agriculture in the U.K. Journal of Environmental Management, 50, 111-128. https://doi.org/10.1006/jema.1996.0103

Stockholm Declaration (1972). Stockholm Declaration on the Human Environment, in the Report of the United Nations Conference on the Human Environment. UN Doc.A/CONF.48/14, at 2 and Corr.1.

Strydon, H. A., \& King, N. D. (2009). Environmental Management in South Africa (2nd ed.). Cape Town: Juta.

Syed, M. G., Bhat, S. J. A., Geelani, S. H., Haq, S. S., Mir, N. A., Qazi, G., \& Wani, S. (2013). Mining and Its Impacts on the Environment with Special Reference to India. International Journal of current research, 5, 3586-3590.

The Environmental Management Act (chapter 20:27) of 2007.

The National Treasury Annual Report (2007/8).

The Parks and Wild Life Act (chapter 20:14) of 2014.

The Sunday Mail (2016). Veld Fires Remain the Biggest Challenge for Zimbabwe. https://www.sundaymail.co.zw/veld-fires-remain-biggest-challenge-for-zim

Tilton, J. E. (2016). Global Climate Policy and the Polluter Pays Principle: A Different Perspective. Resource Policy, 50, 117-118. https://doi.org/10.1016/j.resourpol.2016.08.010

Tinsley, S., \& Pillai, I. (2012). Environmental Management Systems: Understanding Organisational Drivers and Barriers. London: Routledge. https://doi.org/10.4324/9781849771214

Vishwanath, P. M., Pandey, P., \& Bhargava, A. (2017). Water Pollution-Global Perspective with Special Reference to India. Journal of Bio-Innovation, 6, 853-863. 